\title{
Effects of Grassland Fire on Selected Properties of Soil in the Savannah Region of Nigeria
}

\author{
Abdulraheem, K. A. ${ }^{1}$, Aremu, A. S. ${ }^{1}$, Adeniran, J. A. ${ }^{2 *}$, Yusuf, M. N. O. ${ }^{2}$, Odediran, E.T. ${ }^{2}$, \\ Ismail, A. ${ }^{3}$, Sonibare, J. A. ${ }^{4}$ \\ ${ }^{1}$ Department of Civil Engineering, University of Ilorin, Ilorin, Nigeria \\ ${ }^{2}$ Environmental Engineering Research Laboratory, Department of Chemical Engineering, University of Ilorin, Ilorin, \\ Nigeria \\ ${ }^{3}$ Department of Water Resources and Environmental Engineering, Ahmadu Bello University, Zaria, Nigeria \\ ${ }^{4}$ Environmental Engineering Research Laboratory, Department of Chemical Engineering, Obafemi Awolowo \\ University, Ile-Ife, Osun State, Nigeria
}

*Corresponding Author E-mail: adeniran.ja@ unilorin.edu.ng; $\quad$ Tel: +234 8033660981

Submitted on: 11/02/2021

Accepted on: 07/04/2021

\begin{abstract}
The effects of fire on soil properties have been widely studied in different ecosystems globally. However, only limited studies exist in the savanna tropics of Africa with mostly inconsistent results. The objective of this study is to characterize the effects of different fire intensities on soil properties in the Guinea Savannah of Nigeria through laboratory experiments. Three different grass species (Eleusine indica, Cynodon dactylon and Imperata cylindrica) and soils were collected from the forest zone of the University of Ilorin and prepared for laboratory investigation. Experimental fires were simulated in the laboratory to replicate field burning conditions on the prepared plots to determine precise effects of fire on soil properties. Three fire treatments (low, moderate and high) were considered, while the pre-burning and post burning samples of soils were taken for laboratory investigation, and the results statistically analyzed. The $\mathrm{pH}$ was observed to have increased between the range of 7.92 to 8.37 . The average percentage decrease in organic matter content is 5\%, 33\% and $69 \%$ for low, moderate and high fire intensities, respectively. For total nitrogen, 8\%, 16\%, and $19 \%$ increase; calcium, $17 \%, 117 \%$ and $283 \%$ increase; magnesium, $11 \%, 30 \%$ and $84 \%$ increase; sodium, 7\%, 20\% and 54\% increase; potassium, 24\%, 20\% and 49\% decrease; available phosphorus, $8 \%, 18 \%$ and $29 \%$ increase. The results show the impacts of prescribed fire in the management of savanna ecosystem.
\end{abstract}

Keywords: Soil properties, Savannah fires, Organic matter, Fire intensity

\section{Introduction}

Soil is an essential constituent of the earth surface that is crucial for human survival (Alcañiz et al., 2018; Pereira et al., 2018). The vital roles played by soils towards the stability of the ecosystem in the areas of biodiversity, climate change, food security, disease control, and a sustainable global economy cannot be overemphasized (Pereira et al., 2018). The aggregate structure of a soil is significant for its optimum response that includes biogeochemical dynamics, carbon stocks, topsoil hydrology and root development (Thomaz and Fachin, 2014). Fire is identified among the agents that easily degrade the structure of a soil. This occurrence is most frequent in tropical regions with some remarkable peculiarities that make them susceptible to fire (Silva Junior et al., 2018). Most often, fire causes damages on the major components of the ecosystem in addition to accelerated processes of soil degradation (Ratajczak et al., 2018; Bär et al., 2019; Abdulraheem et al., 2020). Fire may lead to loss of nutrients by inhibiting cellulosic substances in grasses, release of toxic elements that are mostly biomarkers for diseases in humans, as well as contamination of the water table, depending on its intensity, severity and reoccurrence (Hood et al., 2018; Oliveira-Filho et al., 
2018; Hohner et al., 2019; Kowaljow et al., 2019). Other important parameters of soil affected by fire include chemical and biological properties which results to the degradation of essential minerals in the soil by heat (Thomaz and Fachin, 2014; Fonseca et al., 2017).

Fires are classified as prescribed fires and wildfires depending on its precipitated sources. Prescribed fires are essentially forest management practice that involve the controlled burning of herbaceous vegetation for the purpose of reducing the amount of available vegetation fuel (Bridges et al., 2019) whereas wildfires occur spontaneously due to high loadings of dry fuels (Pausas and Keeley, 2019; Sayad et al., 2019). The occurrence of wildfire is more frequent in the savanna regions of Africa due to the presence of highly lignified plant species (Scholes et al., 2011; Gatebe et al., 2014; Kouassi et al., 2020), though prescribed fires are preferable to minimize the risks of wildfire due to high intensity usually accompanied with wildfire as well as other adverse influences on the soil (Fonseca et al., 2017; Alcañiz et al., 2018). The Guinea savanna vegetation of Nigeria experiences this kind of high intensity fires on an annual basis during dry seasons (FGN, 2019) which is discovered to be influenced by both natural and anthropogenic forces (Keeley and Syphard, 2018; Nagy et al., 2018). The latter is usually aided by uncontrolled burnings in the Guinea savanna vegetation, as the locals intentionally reduce crowded plants that have little to no significant benefits during land preparation for a new planting season.

Valderrama et al. (2018) revealed that soil receives the most damaging effects from the outbreak of fire since it is responsible for nutrient reservoir for plant in addition to the provision of their physical support. Other physical properties of soil that may be altered during fire episodes include; $\mathrm{pH}$, colour, texture, bulk density and soil biota (Quintano et al., 2019). Soil aggregate properties such as aggregate stability, water repellence, water retention, soil carbon depletion and other physicochemical properties such as organic carbon, electrical conductivity, $\mathrm{pH}$ and organic matter (Thomaz and Fachin, 2014; Kamble, 2021) are also affected during fire episodes. The ability of the soil to recover from this kind of degradation depends on some interdependent factors such as fire characteristics, ash properties, topography, vegetation recuperation, post-fire weather and management (Pereira et al., 2018). The impacts of fire on soil chemical and biological properties varies widely and is dependent on factors such as soil type, vegetation type, fire magnitude, moisture content of the soil, as well as pre and post fire environmental conditions (Alcañiz et al., 2016; NgoleJeme, 2019).

Soil nutrients are found to be affected by series of developments during and immediately after being subjected to fire. These phases of development include ash convection, volatilization, mineralization, erosion, runoff and leaching (Neary et al., 1999; Gómez-Sánchez et al., 2019). Every nutritional element reacts differently to heat since each element has a specific threshold temperature, that is. the temperature where a development occurs (DeBano, 1990; Pellegrini and Jackson, 2020). Threshold temperatures of stable elements can be classified into three categories; Sensitive (Nitrogen and Sulphur with threshold temperature between $200-300{ }^{\circ} \mathrm{C}$ ), Moderately sensitive (Potassium and Phosphorus with threshold temperature of $774{ }^{\circ} \mathrm{C}$ ) and Relatively sensitive (Magnesium, Calcium and Manganese with threshold temperature between $1107-1962{ }^{\circ} \mathrm{C}$ ) (DeBano, 1990). Fire intensity is a measure of fuel energy which is directly proportional to the amount of fuel consumed by the fire (De Marco et al., 2005). This implies that higher amounts of energy would be released from fire with a corresponding larger amount of grass species serving as fuel load during burning episodes, with the same fuel type, at similar weather conditions and uniform topography. This research study aims to characterize the effects of different magnitudes of fire on soil properties in savanna regions in Nigeria through laboratory experiments and to evaluate the potential risks of fire on certain soil conditions. 
LAUTECH Journal of Civil and Environmental Studies

Volume 6, Issue 2

\section{Materials and Methods}

The study area selected for the collection of grass samples is located within the University of Ilorin forest zone which lies within the Guinea savanna vegetation of the country. The area has a mean annual rainfall of about 1000-1500 mm that last between 6-8 months and mean annual temperature of $28-31^{\circ} \mathrm{C}$. The Guinea savannah vegetation is characterized by open woodland, tall grasses with growth of about 1-3 $\mathrm{m}$ in height and deciduous trees having exceedingly thick trunks with width of about $5 \mathrm{~m}$. Fire resistant species predominate the region as a result of the region's susceptibility to extreme fires that occur mostly during the dry seasons. The soils found in the region are laterite (deeply greyish or reddish in colour) and rich lava soils that are suitable for crop productions (FGN, 2019).

Experimental fires were simulated in the laboratory to replicate field burning conditions while determining the precise effects of fire on the soil properties. The experimental method was based on previous studies of (Campo et al., 2008; Bridges et al., 2019). Three different species of grasses that served as fuel elements and three levels of fire intensity were specified. The burning area that was used to carry out the experiment was located within the University of Ilorin - the foundry section of the Department of Materials and Metallurgical, where safety considerations was giving the maximum priority. Three samples of mineral soil were collected from three different portions of the grassland where different grass species are dominated at; of which each portion was marked $0.25 \mathrm{~m}$ $\mathrm{x} 0.25 \mathrm{~m}$ and a depth of $0.1 \mathrm{~m}$ after the removal of contaminants from the surface soils. A control sample was also collected from a random area, totalling the samples to ten (10) samples. The soils that were collected were spread evenly to reproduce the existing field conditions (Fig. 1). A representative and effective method of soil sampling where $10 \mathrm{~cm}$ core was taken in zigzag path to ensure adequate mixing of soil sample was applied and done for each plot (Jackson, 1958). To avoid transfer of contaminant during sample collection, the trowel was cleaned after every use.

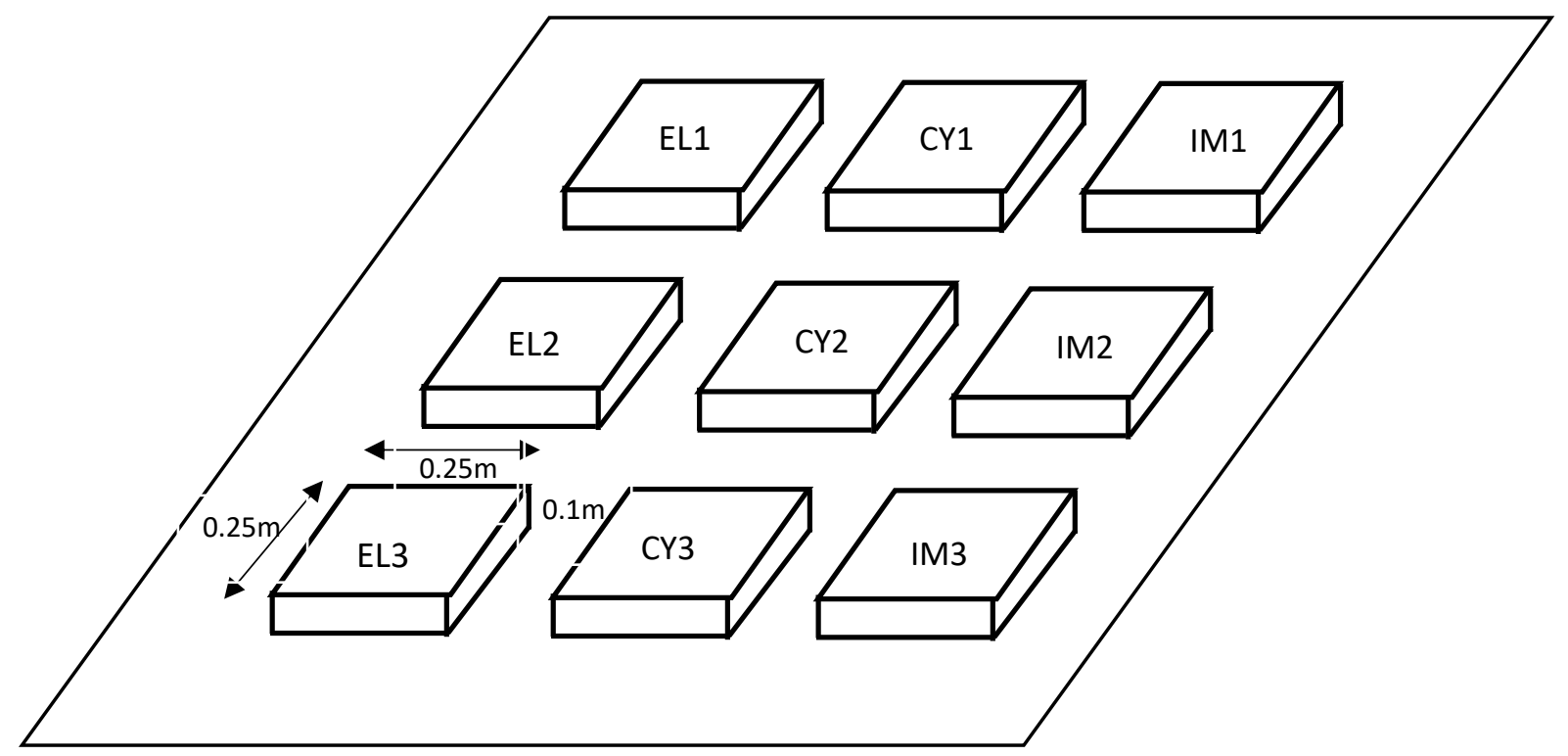

Figure 1. Schematic representation of the experimental burn plots

Three different grass species (Eleusine indica, Cynodon dactylon, and Imperata cylindrica) were used as fuels for the experiment at low, moderate and high density. The soils were collected at the same location as the grasses to reproduce exact field conditions. The grasses were picked from their respective locations/areas based on their density; an area of $0.25 \mathrm{~m}$ x $0.25 \mathrm{~m}$ quadrant plot was 
measured around the identified grasses. Each grass specie collected was weighed to determine its mass. This procedure was repeated for all the three grass species together with their density classifications (Table 1). Each group of grasses was kindled with a propane lighter at every burning experiment. Soil samples from the post-burning experiments were collected, carefully wrapped in aluminium foil sheets and placed inside an air-tight polythene before taking to the laboratory for analyses.

Table 1. Mass of sampled grass species

\begin{tabular}{lccc}
\hline \multicolumn{1}{c}{ Grass species } & Low $(\mathrm{g})$ & Moderate $(\mathrm{g})$ & High $(\mathrm{g})$ \\
\hline & 1 & 2 & 3 \\
Eleusine Indica $($ EL) & 15.94 & 18.27 & 41.53 \\
Cynodon dactylon $($ CY $)$ & 2.76 & 25.24 & 31.28 \\
Imperata cylindrica $(I M)$ & 8.83 & 41.55 & 78.84 \\
\hline
\end{tabular}

The soil properties taken in the pre-and post-burning analyses include soil $\mathrm{pH}$, organic matter, organic carbon, total nitrogen, exchangeable bases $(\mathrm{Ca}, \mathrm{Mg}, \mathrm{Na}$ and $\mathrm{K})$ and available Phosphorus. The soil $\mathrm{pH}$ was determined using an electronic Jenway $3015 \mathrm{pH}$ meter at a ratio of 1:2.5 (soil: water ratio). The total organic carbon in the sediment was determined using hydrogen peroxide digestion method (Schumacher, 2002). Total Nitrogen was determined using Kjeldahl method (Sáez-Plaza et al., 2013). Exchangeable bases ( $\mathrm{Ca}$ and $\mathrm{Mg}$ ) were determined using EDTA titration method (Motsara and Roy, 2008). Available $\mathrm{K}$ and $\mathrm{Na}$ were determined using the flame photometer while available phosphorus was determined using Bray's method No. 1 (Motsara and Roy, 2008)

\section{Results and Discussion}

\section{Soil pH}

The values obtained from the results of the $\mathrm{pH}$ of the soil samples after burning were found to have insignificant variations for all grass species and classifications (low, moderate and high) (Fig. 2). A slight increase in $\mathrm{pH}$ was observed in the three grass species (EL, CY and IM) considered in the study with a range of $7.92-8.37$. The coefficient of variation for CY, EL, and IM are 3\%, 2\%, and $<1 \%$, respectively. Thus, the effect of prescribed fire on the soil $\mathrm{pH}$ in this study is insignificant.

It was observed that an overall but insignificant increase in $\mathrm{pH}$ for the three sample species (fuel types) and categories at different levels of fire treatment. This is consistent with the study of (Alcañiz et al., 2016) who observed an insignificant increase in $\mathrm{pH}$ immediately after a prescribed fire was simulated. The alteration in the $\mathrm{pH}$ of the soils might have resulted from the mixture of alkaline ions and oxides contained in the ash formed during post-burning operation of biotic matters that are deposited on the soil (Fonseca et al., 2017). According to Bridges et al. (2019) significant increase in soil $\mathrm{pH}$ could likely be attained at burning temperature exceeding $450^{\circ} \mathrm{C}$. This strongly explains the insignificant increase in $\mathrm{pH}$ observed in this study because the burning temperature was kept below the reported temperature.

\section{Organic matter}

The result obtained for the organic matter (OM) found in the soil samples shows their variations across each plot area (Table 2). Significant variations were observed according to the increased fire intensity. The average percentage decrease in OM content for EL, CY and IM species for categories 1,2 , and 3 are $5 \%, 33 \%$ and $69 \%$, respectively. The organic matter contents in all the soil samples subjected to different levels of fire treatments were observed to have reduced considerably. Reduction in OM was previously reported by (Fonseca et al., 2017) to have greatly reduced in low intensity fires. Likewise, in this study, organic matter in soils is also minimally impacted when exposed to low intensity fires. Although, loss of OM in soil begins slowly at lower temperature but 


\section{LAUTECH Journal of Civil and Environmental Studies}

\section{Volume 6, Issue 2}

later results to high degradation of about of $85 \%$ when temperatures ranging between $200-300{ }^{\circ} \mathrm{C}$ is about to be reached (Tulau and McInnes-Clarke, 2015). Soil OM may be exposed to minor distillation, charring and complete oxidation depending on the intensity of the fire (Certini, 2005). Thus, factors such as fire intensity, severity, type, topography, moisture content and ecosystem determine the effects of fire on soil OM (Verma and Jayakumar, 2012; Fonseca et al., 2017; Alcañiz et al., 2018). In this study, it was observed that EL3, CY3 and IM3 have higher reduction in OM content compared to the other category while EL3 had the highest reduction rate in all.
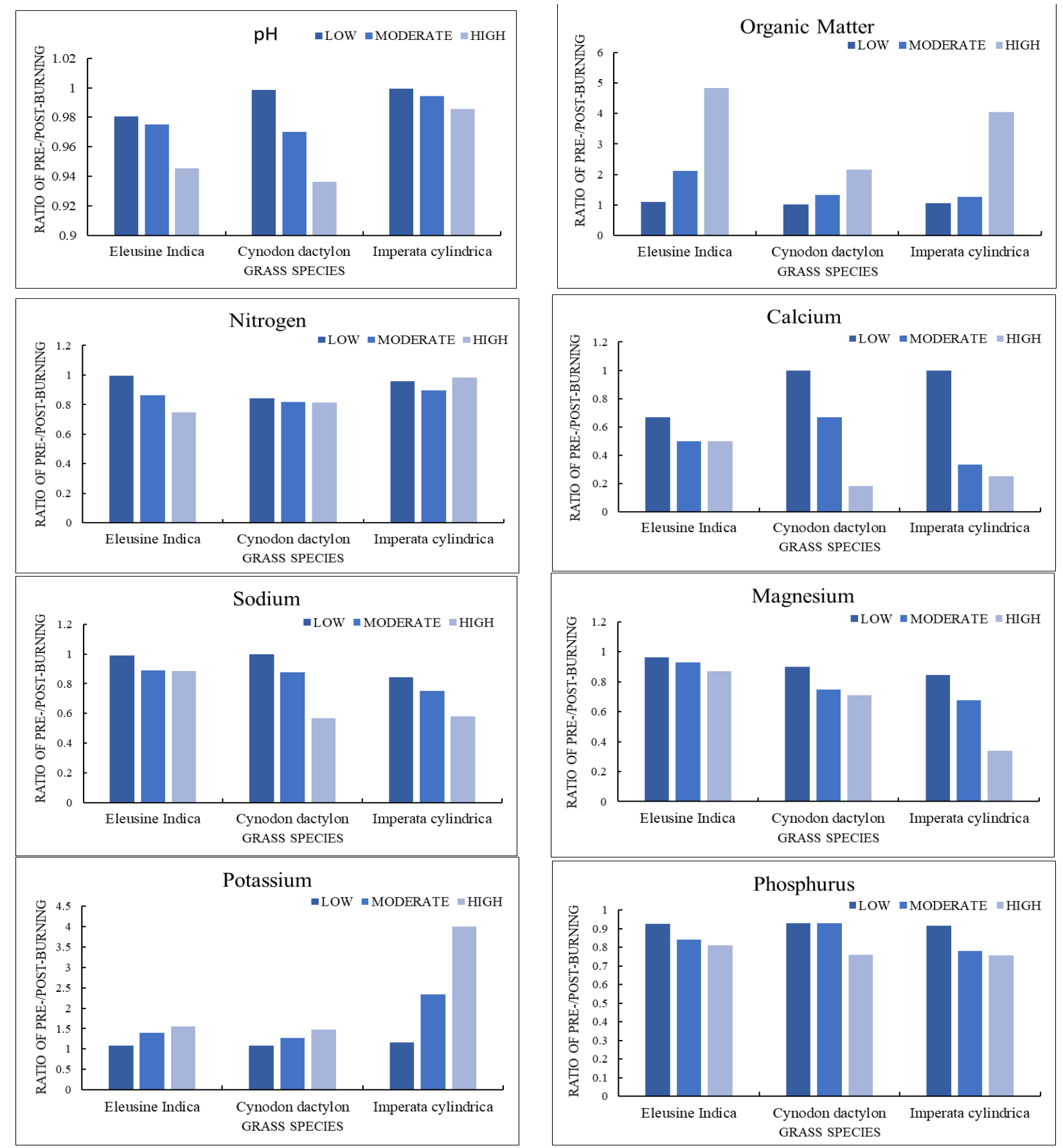

Figure 2. Ratio of pre-burning to post-burning for $\mathrm{pH}$, organic matter, Nitrogen, Calcium, Sodium, Magnesium, Potassium and Phosphorus for selected grasses. 
Table 2. Mean values of post-burning soil parameters in Low (1), Moderate (2) and High (3) fire intensity treatments

\begin{tabular}{lccccccccc}
\hline $\begin{array}{c}\text { Soil } \\
\text { Parameters }\end{array}$ & \multicolumn{3}{c}{ Eleusine indica } & \multicolumn{3}{c}{ Cynodon dactylon } & \multicolumn{3}{c}{ Imperata cylindrica } \\
\hline & EL1 & EL2 & EL3 & CY1 & CY2 & CY3 & IM1 & IM2 & IM3 \\
$\mathrm{pH}$ & 8.07 & 9.37 & 8.11 & 8.16 & 8.45 & 7.92 & 8.03 & 7.92 & 7.96 \\
$\mathrm{OM}(\%)$ & 3.01 & 1.32 & 5.81 & 4.79 & 7.95 & 6.22 & 6.05 & 5.00 & 1.57 \\
$\mathrm{~N}(\%)$ & 0.43 & 0.61 & 1.11 & 0.34 & 1.38 & 1.11 & 1.18 & 1.05 & 0.50 \\
$\mathrm{Ca}(\mathrm{Cmol} / \mathrm{kg})$ & 0.09 & 0.01 & 0.02 & 0.01 & 0.06 & 0.02 & 0.04 & 0.01 & 0.03 \\
$\mathrm{Na}(\mathrm{Cmol} / \mathrm{kg})$ & 0.22 & 0.20 & 0.61 & 0.44 & 0.95 & 0.61 & 0.64 & 0.41 & 0.23 \\
$\mathrm{Mg}(\mathrm{Cmol} / \mathrm{kg})$ & 0.07 & 0.07 & 0.06 & 0.05 & 0.18 & 0.09 & 0.16 & 0.07 & 0.04 \\
$\mathrm{~K}(\mathrm{Cmol} / \mathrm{kg})$ & 0.09 & 0.04 & 0.13 & 0.10 & 0.34 & 0.13 & 0.12 & 0.06 & 0.04 \\
$\mathrm{P}(\mathrm{mg} / \mathrm{kg})$ & 0.29 & 0.26 & 1.43 & 0.53 & 1.24 & 1.24 & 0.26 & 0.48 & 0.33 \\
\hline
\end{tabular}

\section{Total Nitrogen}

Total Nitrogen was observed to have increased in all the sample species and categories. The average increase in the total nitrogen is found to be $8 \%, 16 \%$, and 19\% for EL1, CY1 and IM1; EL2, CY2 and IM2; and EL3, CY3 and IM3, respectively. The coefficient of variation for CY, EL and IM are $2 \%, 14 \%$ and $5 \%$, respectively. Total nitrogen was observed to increase in all plot area, with the highest increase recorded in EL3, CY3 and IM3 due to higher fuel load (grass density). The present nitrogen compounds are likely in the forms of $\mathrm{NH}_{4}-\mathrm{N}$ and $\mathrm{NO}_{3}-\mathrm{N}$ which increase immediately after each fire episode (Verma et al., 2019). Küçük and Kahveci (2020) reported that there is an increased $\mathrm{N}$-mineralization occurring with increased fire severity for typical grassland communities. The net $\mathrm{N}$-mineralization may perhaps be related to factors such as; the total nitrogen contents of the soils, unregulated burning procedures and organic matter deposition unto the soil (Nardoto and Bustamante, 2003). Earlier studies have reported a significant increase in total nitrogen immediately after prescribed fire had taken place (Alcañiz et al., 2016; Reinhart et al., 2016; Francos et al., 2018). On the other hand, volatilization of nutrients that is precipitated by fire is also an important effect on soils. Direct loss of nutrients in the soil to the atmosphere after a fire occurrence is however dependent on burning temperature because nitrogen begins to volatilize at $200{ }^{\circ} \mathrm{C}$ as other nutrients are found to volatilize at higher temperatures (Neary et al., 1999; Wittkuhn et al., 2017). At a temperature of $200{ }^{\circ} \mathrm{C}$ or below, elemental nitrogen is slightly lost, but at higher temperature organic nitrogen is converted to ammonium ions and later to $\mathrm{NO}_{3}$ due to nitrification which gets leached rapidly and out of the available nutrient pool (Tulau and McInnes-Clarke, 2015).

\section{Exchangeable Bases ( $\mathrm{Ca}, \mathrm{Mg}$, $\mathrm{Na}$ and $\mathrm{K}$ )}

Calcium was observed to increase significantly in all the sample species and categories. The average percentage increase of $17 \%$ was observed in EL1, CY1 and IM1 while EL2, CY2 and IM2 increased at an average of $117 \%$ and EL3, CY3 and IM3 at 283\%. The order of increase for calcium content in the sample species was observed from the least to the highest fire intensities; with CY3, IM3 and EL3 having values of $0.05,0.04$ and $0.02 \mathrm{cmol} / \mathrm{kg}$, respectively. These observations implied that calcium slowly degrades with increasing fire intensity. Hence fire has substantial effect on the calcium content in the soil samples studied. Similarly, magnesium increased in all fuel types and fire treatments with an average of $11 \%$ for EL1, CY1 and IM1, 30\% for EL2, CY2 and IM2; while EL3, CY3 and IM3 increased at 84\%. The coefficient of variation for Mg for EL is the highest with $5 \%, 12 \%$ for CY and 51\% for IM. Conversely, sodium levels vary across the treatments and fuel 


\section{LAUTECH Journal of Civil and Environmental Studies}

Volume 6, Issue 2

types. The results showed an increase in Na levels for all treatments. An average increase of $7 \%$ was observed in EL1, CY1 and IM1, 20\% was observed for EL2, CY2 and IM2 while EL3, CY3 and IM3 had an average increase of 54\%. For Potassium (K), overall reduction was also observed in Potassium for all treatments. 24\% average reduction was observed in EL1, EL2 and EL3, 20\% in CY1, CY2 and CY3 while $49 \%$ in IM1, IM2 and IM3.

Available $\mathrm{Ca}, \mathrm{Mg}$ and $\mathrm{Na}$ were higher in all the fire treatments levels and fuel types immediately after the prescribed fire. Increased nutrients after burning episodes were reported in the study of (Pereira et al., 2017; Francos et al., 2018) where ash deposition on the soil surface during burning is found to promote the increase of the present $\mathrm{Ca}$ and $\mathrm{Mg}$ found in the soils due to the alkalization effect (Oliveira-Filho et al., 2018). However, Gómez-Rey et al. (2013) observed no change in Na concentrations after fire contrary to our observation in this study. Potassium content was lower in all treatments and fuel types. The effects of fire on potassium have been studied by a wide range of researchers. However, the results of these studies have been inconsistent. For instance, reduction in exchangeable $\mathrm{K}$ in soil immediately after fire was described by (Bridges et al., 2019; Verma et al., 2019; Alcañiz et al., 2020) while (Kutiel and Shaviv, 1992; Lucas-Borja et al., 2019) reported an increase in K immediately after burning. Pivello et al. (2010) have also observed that available Ca, $\mathrm{Mg}$ and $\mathrm{K}$ are not really affected by the fire but at the time of burning but by the frequency of fire in the ecosystem.

\section{Available Phosphorus}

Available phosphorus increased in all fire treatment levels. EL1, CY1 and IM1 increased with an average of $8 \%$, EL2, CY2 and IM2 increased at $18 \%$ while EL3, CY3 and IM3 increased at $29 \%$. The coefficient of variation for P for EL is $7 \%$, whereas it was $12 \%$ for CY and $10 \%$ for IM. Available phosphorus increased in all the plots in this study. Significant increase in available phosphorus were observed after wildfire and experimental fire in Spain (Gómez-Rey et al., 2013; Badía et al., 2014). Alcañiz et al. (2020) reported remarkable increase in available phosphorus and concluded that the increase was caused as by high temperature burning which resulted to mineralization and OM combustion. Litton and Santelices (2003) stated that phosphorus is usually not volatilized and readily available phosphorus present in ash is integrated back into the soil after precipitation.

\section{Conclusion}

In this study, changes in soil properties were examined, to determine the effects of prescribed fire. This study revealed an increased level in the soil $\mathrm{pH}$, total Nitrogen, $\mathrm{Ca}, \mathrm{Mg}, \mathrm{P}$ and $\mathrm{Na}$ while potassium and organic matter content decreased. The effects of fire on these soil properties are usually variable which is dependent on the magnitude of fire, moisture content, environmental conditions, and soil type. Although this study examined the immediate effects of prescribed fire on three different grass species, there is no indication that the grasses types have any influence on the parameters considered. Thus, it is recommended to advance the study to validate the influence of some other factors on the long-term effect of fire and how they individually affect soil nutrients.

\section{Acknowledgment}

This work was supported by the Tertiary Education Trust Fund (TETFUND) of the Ahmadu Bello University - Zaria, Nigeria, under the no. DAPM/TETFUND/01/13.

\section{References}

Abdulraheem, K. A., Adeniran, J. A., Aremu, A. S., Yusuf, M.-N. O., Adebisi, J. A., Sadiku, N. A., Olofintoye, O. O., Ismail, A., \& Sonibare, J. A. (2020). Emission factors of some common grass species 
in West Africa. Environmental monitoring and assessment, 192(12), 1-16. doi:https://link.springer.com/article/10.1007/s10661-020-08725-0

Alcañiz, M., Outeiro, L., Francos, M., Farguell, J., \& Úbeda, X. (2016). Long-term dynamics of soil chemical properties after a prescribed fire in a Mediterranean forest (Montgrí Massif, Catalonia, Spain). Science of the Total Environment, 572, 1329-1335. doi:https://link.springer.com/article/10.1007/s11104-012$1408-\mathrm{z}$

Alcañiz, M., Outeiro, L., Francos, M., \& Úbeda, X. (2018). Effects of prescribed fires on soil properties: a review. Science of the Total Environment, 613, 944-957. doi:https://doi.org/10.1016/j.scitotenv.2017.09.144

Alcañiz, M., Úbeda, X., \& Cerdà, A. (2020). A 13-Year approach to understand the effect of prescribed fires and livestock grazing on soil chemical properties in Tivissa, NE Iberian Peninsula. Forests, 11(9), 1013. doi:https://doi.org/10.3390/f11091013

Badía, D., Martí, C., Aguirre, A. J., Aznar, J. M., González-Pérez, J., De la Rosa, J., León, J., Ibarra, P., \& Echeverría, T. (2014). Wildfire effects on nutrients and organic carbon of a Rendzic Phaeozem in NE Spain: changes at cm-scale topsoil. Catena, 113, 267-275. doi:https://doi.org/10.1016/j.catena.2013.08.002

Bär, A., Michaletz, S. T., \& Mayr, S. (2019). Fire effects on tree physiology. New Phytologist, 223(4), 17281741. doi: https://doi.org/10.1111/nph.15871

Bridges, J. M., Petropoulos, G. P., \& Clerici, N. (2019). Immediate Changes in Organic Matter and Plant Available Nutrients of Haplic Luvisol Soils Following Different Experimental Burning Intensities in Damak Forest, Hungary. Forests, 10(5), 453. doi:https://doi.org/10.3390/f10050453

Campo, J., Gimeno-García, E., Andreu, V., González-Pelayo, O., \& Rubio, J. L. (2008). Aggregation of under canopy and bare soils in a Mediterranean environment affected by different fire intensities. Catena, 74(3), 212-218. doi:https://doi.org/10.1016/j.catena.2008.05.002

Certini, G. (2005). Effects of fire on properties of forest soils: a review. Oecologia, 143(1), 1-10. doi:https://link.springer.com/article/10.1007\%2Fs00442-004-1788-8

De Marco, A., Gentile, A. E., Arena, C., \& De Santo, A. V. (2005). Organic matter, nutrient content and biological activity in burned and unburned soils of a Mediterranean maquis area of southern Italy. International Journal of Wildland Fire, 14(4), 365-377. doi:https://doi.org/10.1071/WF05030

DeBano, L. F. (1990). The effect of forest fire on soil properties. Paper presented at the Symposiam on Management and Productivity of Western- Montane Forest Soil. , 151-156, Boise, ID, USA.

FGN. (2019). National Forest Reference Emission Level (FREL) for the Federal Republic of Nigeria Retrieved from https://redd.unfccc.int/files/2019_submission_frel_nigeria.pdf

Fonseca, F., de Figueiredo, T., Nogueira, C., \& Queirós, A. (2017). Effect of prescribed fire on soil properties and soil erosion in a Mediterranean mountain area. Geoderma, 307, 172-180. doi:https://doi.org/10.1016/j.geoderma.2017.06.018

Francos, M., Pereira, P., Alcañiz, M., \& Úbeda, X. (2018). Post-wildfire management effects on short-term evolution of soil properties (Catalonia, Spain, SW-Europe). Science of the Total Environment, 633, 285292.

Gatebe, C., Ichoku, C., Poudyal, R., Román, M., \& Wilcox, E. (2014). Surface albedo darkening from wildfires in northern sub-Saharan Africa. Environmental Research Letters, 9(6), 065003. doi:https://iopscience.iop.org/article/10.1088/1748-9326/9/6/065003/meta

Gómez-Rey, M. X., Couto-Vázquez, A., García-Marco, S., \& González-Prieto, S. J. (2013). Impact of fire and post-fire management techniques on soil chemical properties. Geoderma, 195, 155-164. doi:https://doi.org/10.1016/j.geoderma.2012.12.005

Gómez-Sánchez, E., Lucas-Borja, M., Plaza-Álvarez, P., González-Romero, J., Sagra, J., Moya, D., \& De Las Heras, J. (2019). Effects of post-fire hillslope stabilisation techniques on chemical, physicochemical and microbiological soil properties in mediterranean forest ecosystems. Journal of environmental management, 246, 229-238. doi:https://doi.org/10.1016/j.jenvman.2019.05.150

Hohner, A. K., Rhoades, C. C., Wilkerson, P., \& Rosario-Ortiz, F. L. (2019). Wildfires alter forest watersheds and threaten drinking water quality. Accounts of Chemical Research, 52(5), 1234-1244. doi:https://doi.org/10.1021/acs.accounts.8b00670 
LAUTECH Journal of Civil and Environmental Studies

\section{Volume 6, Issue 2}

Hood, S. M., Varner, J. M., van Mantgem, P., \& Cansler, C. A. (2018). Fire and tree death: understanding and improving modeling of fire-induced tree mortality. Environmental Research Letters, 13(11), 113004. doi:https://doi.org/10.1088/1748-9326/aae934

Jackson, M. (1958). Soil chemical analysis prentice Hall. Inc., Englewood Cliffs, NJ, 498, 183-204.

Kamble, R. (2021). Impacts of Controlled Forest Fires on Soil Properties in Gadchiroli Forest Circle, Central India. Sustainability, Agri, Food and Environmental Research.

Keeley, J. E., \& Syphard, A. D. (2018). Historical patterns of wildfire ignition sources in California ecosystems. International Journal of Wildland Fire, 27(12), 781-799. doi:https://doi.org/10.1071/WF18026

Kouassi, J.-L., Wandan, N., \& Mbow, C. (2020). Predictive modeling of wildfire occurrence and damage in a tropical savanna ecosystem of West Africa. Fire, 3(3), 42. doi: https://doi.org/10.3390/fire3030042

Kowaljow, E., Morales, M. S., Whitworth-Hulse, J. I., Zeballos, S. R., Giorgis, M. A., Rodríguez Catón, M., \& Gurvich, D. E. (2019). A 55-year-old natural experiment gives evidence of the effects of changes in fire frequency on ecosystem properties in a seasonal subtropical dry forest. Land Degradation \& Development, 30(3), 266-277. doi: https://doi.org/10.1002/ldr.3219

Küçük, M., \& Kahveci, U. (2020). Determination of short-term effects of wild fire on soil properties and nitrogen mineralization in Turkish pine (Pinus brutia ten.) in Turkey (the case of sariçiçek sub-district directorate). doi:http://dx.doi.org/10.15666/aeer/1806_83558371

Kutiel, P., \& Shaviv, A. (1992). Effects of soil type, plant composition and leaching on soil nutrients following a simulated forest fire. Forest Ecology and Management, 53(1-4), 329-343. doi:https://doi.org/10.1016/0378-1127(92)90051-A

Litton, C. M., \& Santelices, R. (2003). Effect of wildfire on soil physical and chemical properties in a Nothofagus glauca forest, Chile. Revista Chilena de Historia Natural, 76(4), 529-542.

Lucas-Borja, M., Plaza-Álvarez, P., Gonzalez-Romero, J., Sagra, J., Alfaro-Sánchez, R., Zema, D., Moya, D., \& de Las Heras, J. (2019). Short-term effects of prescribed burning in Mediterranean pine plantations on surface runoff, soil erosion and water quality of runoff. Science of the Total Environment, 674, 615622. doi:https://doi.org/10.1016/j.scitotenv.2019.04.114

Motsara, M., \& Roy, R. N. (2008). Guide to laboratory establishment for plant nutrient analysis (Vol. 19): Food and Agriculture Organization of the United Nations Rome.

Nagy, R., Fusco, E., Bradley, B., Abatzoglou, J. T., \& Balch, J. (2018). Human-related ignitions increase the number of large wildfires across US ecoregions. Fire, 1(1), 4. doi:https://doi.org/10.3390/fire1010004

Nardoto, G. B., \& Bustamante, M. M. d. C. (2003). Effects of fire on soil nitrogen dynamics and microbial biomass in savannas of Central Brazil. Pesquisa Agropecuária Brasileira, 38(8), 955-962. doi:https://doi.org/10.1590/S0100-204X2003000800008.

Neary, D. G., Klopatek, C. C., DeBano, L. F., \& Ffolliott, P. F. (1999). Fire effects on belowground sustainability: a review and synthesis. Forest Ecology and Management, 122(1-2), 51-71. doi:https://doi.org/10.1016/S0378-1127(99)00032-8

Ngole-Jeme, V. M. (2019). Fire-Induced Changes in Soil and Implications on Soil Sorption Capacity and Remediation Methods. Applied Sciences, 9(17), 3447. doi:https://doi.org/10.3390/app9173447

Oliveira-Filho, E. C., Brito, D. Q., Dias, Z. M., Guarieiro, M. S., Carvalho, E. L., Fascineli, M. L., Niva, C. C., \& Grisolia, C. K. (2018). Effects of ashes from a Brazilian savanna wildfire on water, soil and biota: An ecotoxicological approach. Science of the Total Environment, 618, 101-111. doi: https://doi.org/10.1016/j.scitotenv.2017.11.051

Pausas, J. G., \& Keeley, J. E. (2019). Wildfires as an ecosystem service. Frontiers in Ecology and the Environment, 17(5), 289-295. doi:https://doi.org/10.1002/fee.2044

Pellegrini, A. F., \& Jackson, R. B. (2020). The long and short of it: A review of the timescales of how fire affects soils using the pulse-press framework. Advances in Ecological Research, 62, 147-171. doi:https://doi.org/10.1016/bs.aecr.2020.01.010

Pereira, P., Cerda, A., Martin, D., Úbeda, X., Depellegrin, D., Novara, A., Martínez-Murillo, J. F., Brevik, E. C., Menshov, O., \& Comino, J. R. (2017). Short-term low-severity spring grassland fire impacts on soil extractable elements and soil ratios in Lithuania. Science of the Total Environment, 578, 469-475. doi:https://doi.org/10.1016/j.scitotenv.2016.10.210 
Pereira, P., Francos, M., Brevik, E. C., Ubeda, X., \& Bogunovic, I. (2018). Post-fire soil management. Current Opinion in Environmental Science \& Health, 5, 26-32. doi:https://doi.org/10.1016/j.coesh.2018.04.002

Pivello, V. R., Oliveras, I., Miranda, H. S., Haridasan, M., Sato, M. N., \& Meirelles, S. T. (2010). Effect of fires on soil nutrient availability in an open savanna in Central Brazil. Plant and Soil, 337(1-2), 111123. doi:https://link.springer.com/article/10.1007/s11104-010-0508-x

Quintano, C., Fernández-Manso, A., Calvo, L., \& Roberts, D. A. (2019). Vegetation and soil fire damage analysis based on species distribution modeling trained with multispectral satellite data. Remote Sensing, 11(15), 1832. doi:https://doi.org/10.3390/rs11151832

Ratajczak, Z., Carpenter, S. R., Ives, A. R., Kucharik, C. J., Ramiadantsoa, T., Stegner, M. A., Williams, J. W., Zhang, J., \& Turner, M. G. (2018). Abrupt change in ecological systems: inference and diagnosis. Trends in ecology \& evolution, 33(7), 513-526. doi:https://doi.org/10.1016/j.tree.2018.04.013

Reinhart, K. O., Dangi, S. R., \& Vermeire, L. T. (2016). The effect of fire intensity, nutrients, soil microbes, and spatial distance on grassland productivity. Plant and Soil, 409(1-2), 203-216. doi:https://link.springer.com/article/10.1007/s11104-016-2957-3

Sáez-Plaza, P., Navas, M. J., Wybraniec, S., Michałowski, T., \& Asuero, A. G. (2013). An overview of the Kjeldahl method of nitrogen determination. Part II. Sample preparation, working scale, instrumental finish, and quality control. Critical Reviews in Analytical Chemistry, 43(4), 224-272. doi:https://doi.org/10.1080/10408347.2012.751787

Sayad, Y. O., Mousannif, H., \& Al Moatassime, H. (2019). Predictive modeling of wildfires: A new dataset and machine learning approach. Fire safety journal, 104, 130-146. doi:https://doi.org/10.1016/j.firesaf.2019.01.006

Scholes, R. J., Archibald, S., \& von MALTITZ, G. (2011). Emissions from fire in Sub-Saharan Africa: the magnitude of sources, their variability and uncertainty. Global Environmental Research, 15(1), 53-63.

Schumacher, B. A. (2002). Methods for the determination of total organic carbon (TOC) in soils and sediments.

Silva Junior, C. H., Aragão, L. E., Fonseca, M. G., Almeida, C. T., Vedovato, L. B., \& Anderson, L. O. (2018). Deforestation-induced fragmentation increases forest fire occurrence in central Brazilian Amazonia. Forests, 9(6), 305. doi:https://doi.org/10.3390/f9060305

Thomaz, E. L., \& Fachin, P. A. (2014). Effects of heating on soil physical properties by using realistic peak temperature gradients. Geoderma, 230, 243-249. doi:https://doi.org/10.1016/j.geoderma.2014.04.025

Tulau, M., \& McInnes-Clarke, S. (2015). Fire and Soils: A review of the potential impacts of different fire regimes on soil erosion and sedimentation, nutrient and carbon cycling, and impacts on water quantity and quality.

Valderrama, L., Contreras-Reyes, J. E., \& Carrasco, R. (2018). Ecological impact of forest fires and subsequent restoration in Chile. Resources, 7(2), 26. doi:https://doi.org/10.3390/resources7020026

Verma, S., \& Jayakumar, S. (2012). Impact of forest fire on physical, chemical and biological properties of soil: A review. Proceedings of the International Academy of Ecology and Environmental Sciences, 2(3), 168.

Verma, S., Singh, D., Singh, A. K., \& Jayakumar, S. (2019). Post-fire soil nutrient dynamics in a tropical dry deciduous forest of Western Ghats, India. Forest Ecosystems, 6(1), 1-9. doi:https://doi.org/10.1186/s40663-019-0168-0

Wittkuhn, R. S., Lamont, B. B., \& He, T. (2017). Combustion temperatures and nutrient transfers when grasstrees burn. Forest Ecology and Management, 399, 179-187. doi:https://doi.org/10.1016/j.foreco.2017.05.037 